\title{
Passivation Level of AISI 316L Aseptic Tank Surface Quantified by On-Site Electrochemical Techniques
}

\author{
Luis Henrique Guilherme ${ }^{a} *$ (D), Assis Vicente Benedetti ${ }^{b}$ (D), Cecilio Sadao Fugivara ${ }^{b}$, Dirk Engelberg ${ }^{c}$ \\ ${ }^{a}$ Soudap Soldas Sanitárias, Araraquara, SP, Brasil. \\ ${ }^{b}$ Universidade Estadual Paulista, Instituto de quimica, Araraquara, SP, Brasil. \\ ${ }^{c}$ The University of Manchester, Department of Materials, Corrosion \& Protection Centre, United \\ Kingdom.
}

Received: December 18, 2021; Revised: January 11, 2022; Accepted: January 13, 2022

\begin{abstract}
Frequently stainless steel AISI 316L aseptic tanks have their passivity and corrosion resistance properties degraded by biofilm formation and localized corrosion processes. Thereby, maintenance projects are performed to repair the surface in food-grade product contact to obtain an aseptic property as defined by ASME BPE. However, the on-site non-destructive testing are limited to the liquid penetrant examination and the average roughness measurement. The on-site open circuit potential and on-site cyclic polarization measurements were conducted using a portable electrochemical minicell. The level of passivation was quantified on the tank surface, and it was performed before and after the repairing maintenance protocol be made. The results of the on-site electrochemical measurements showed a clear difference between as-degraded and repaired surfaces, indicating a sensible response to aseptic surface inspection. The on-site open circuit potential together with the on-site cyclic polarization were considered an advanced tool to support the maintenance projects of the AISI 316L aseptic surfaces.
\end{abstract}

Keywords: On-site cyclic polarization, 316L stainless steel, ASME BPE, Aseptic tank, Localized corrosion, Corrosion monitoring.

\section{Introduction}

The food-grade storage tanks are widely used by food and beverage manufacturing industries in order to stock their final product and, based on this feature, the storage tank require a high aseptic level in the industrial process ${ }^{1}$. Storage tanks usually have large dimensions (20 m diameter and $40 \mathrm{~m}$ height), and they are constructed directly at the permanent installation site into a cold chamber framework that operate from $-20^{\circ} \mathrm{C}$ to $0^{\circ} \mathrm{C}$. The tank inner surface works in contact with food-grade product and requires a high level of conformity regarding the welding and the mechanical polish processes. The final step of manufacturing is related to the chemical passivation treatment that is executed in order to increase the passivation level of the surface.

Traditional on-site inspection techniques do not evaluate the physicochemical interaction of an equipment with the industrial chemical process which it will be exposed, and it is a significant gap to the inspection techniques. One way to solve this gap is related to the application of electrochemical techniques directly at an industrial site. Electrochemical tests provide a precisely way to evaluate the solution-metal interaction, in order to acquire data on the corrosion resistance and the passivation property of stainless steel.

Electrochemical tests are well established techniques employed in studies of corrosion and passivation of stainless steels ${ }^{2-7}$. The use of a micrometric exposed surface area enables more precise evaluation of the electrochemical behavior of stainless steel surfaces ${ }^{8-13}$. State-of-the-art techniques include

*e-mail: lh.guilherme@soudap.com.br microcells installed at the revolving nosepiece of an optical microscope, with coupling between the microcapillary and the sample $e^{9,14,15}$ or another customized system to be used on the laboratory bench ${ }^{12,15}$. However, no portable electrochemical microcell systems have been reported that are suitable for passivated surface inspection of equipment installed at an industrial site.

A collaborative research project conducted by an university and an engineering corporation has been carried out in order to adapt and to transfer the electrochemical techniques from the laboratory bench to the field application, and as a result it was developed a portable electrochemical micro/ minicell ${ }^{16}$ to be used to inspect welds ${ }^{5}$, surfaces finish ${ }^{17}$ and passivated surfaces ${ }^{18,19}$.

Scientific researches and industrial maintenance records demonstrated a close relation between biofilm formation and localized corrosion on AISI 316L stainless steel surface applied in aseptic process $s^{20,21}$. The food-grade product is microbiological contaminated when this phenomenon occurs, and a maintenance project is required to repair the surface to the aseptic quality. However, the maintenance protocols are limited to the liquid penetrant examination and average roughness $(\mathrm{Ra})$ measurements as technique to evaluate the adequacy of the surface to the aseptic applications. The ASME Bio Processing Equipment (ASME BPE) Standard ${ }^{22}$ suggests to use the on-site cyclic polarization measurements to assess the surface and so validate its aseptic properties.

The chemical passivation treatment is recommended by ASME BPE to be carried out for the applications of building 
new plants, after mechanical maintenance and periodically in order to eliminate biofilm and rouge adhesion. The guideline to chemical passivation treatment at the food-grade and life science industries are the ASME BPE and ASTM A-380 Standards ${ }^{23}$, since the state-of-the-art does not offer a large number of articles in this subject. Even though the ASME BPE strongly suggest the use of electrochemical techniques to assess the passivated surface, the standard norm recognizes that this technology is still ongoing. Consequently, the ferroxyl test is the most applied inspection technique to assess the quality of the passivated surface of stainless steel equipment, even if this technique does not offer data of passivation properties and, then, this study intends contributing to fil this lacune in literature of on-site tanks inspection.

This study aims at showing the results of the on-site open circuit potential (OCP) and cyclic potentiodynamic polarization (CPP) measurements obtained during a maintenance project of the orange juice aseptic tank to quantify the passivation level of both surface conditions: degraded and repaired surface. The inspected tank showed biofilm formation and localized corrosion and the electrochemical techniques were used to measure the surface quality increasement in term of passivation property and according to the maintenance service was performed.

\section{Materials and Methods}

The aseptic tank was built using AISI 316L stainless steel in all parts and its mechanical properties and chemical composition are according to ASTM A-24024. The surface defects were detected applying liquid penetrant examination using a procedure based on ASME V Standard ${ }^{25}$ and after that a corrosion traceability map was done. A customized portable macroscopy system using a Canon lens EF $100 \mathrm{~mm}$ F/2.8 L macro IS USM was used to acquire surface images and consequently its morphology characterization. Figure 1 shows the inner tank surface and the typical surface defects related to the localized corrosion, which were responsible for food-grade product contamination. In this study it was observed around 350 spots using the morphological characterization system.

The corrosion spots were repaired using a ASME IX ${ }^{26}$ qualified TIG welding procedure, and as the weld consumable was used the rod grade 308LSi so as to fill the degraded area and allow the surface mechanical polishing, since the weld spot generated a positive weld face reinforcement, as showed in Figure 2.

After repairing all defects, the surface was mechanical polished until reach a surface roughness prolife (Ra: average roughness) equal or less than $0.76 \mu \mathrm{m}$ measured by a portable surface roughness tester Mitutoyo SJ-310. The chemical passivation treatment was performed according to ASME BPE in order to increase the surface corrosion resistance, since this procedure removes the stainless steel surface contaminants as free-iron, and provide a high level of quality to the passive film as its formation carried out in a nitric acid solution. The first step of the passivation

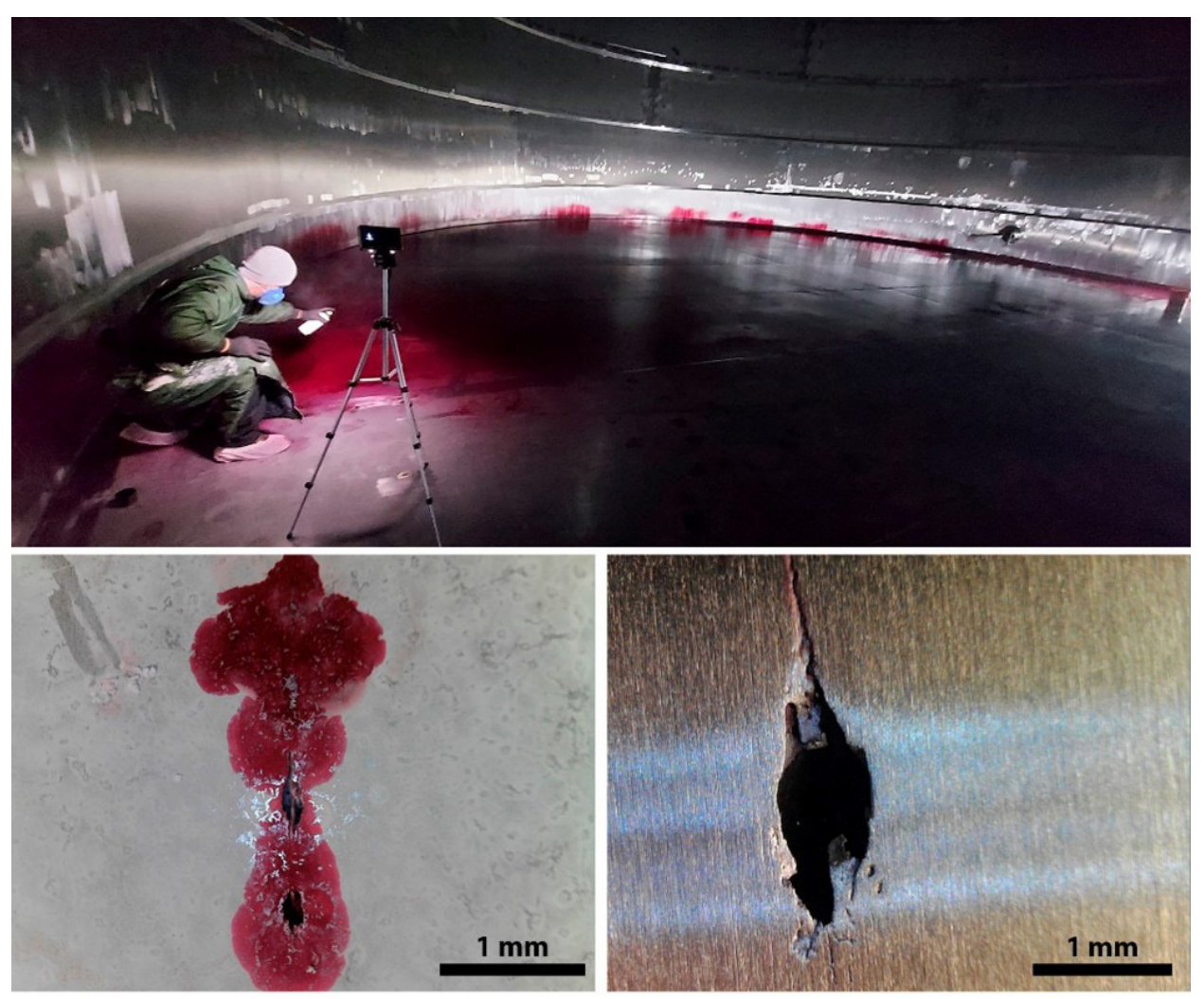

Figure 1. (a) Liquid penetration examination in progress and the respective surface corrosion defects, (b) liquid penetrant residues and (c) the surface after mechanical cleaning to take macrographic pictures. 
treatment was the cleaner process, which was performed during $1 \mathrm{~h}$ using an alkaline solution of $1.5 \%(\mathrm{w} / \mathrm{v}) \mathrm{NaOH}$ and followed by the passivation process that was executed applying a $15 \mathrm{wt} . \%$ nitric acid aqueous solution for $1.5 \mathrm{~h}$. The deionized water was used between the surface cleaning with alkaline and treatment with the acid electrolyte with the purpose of flush the surface. The chemical passivation

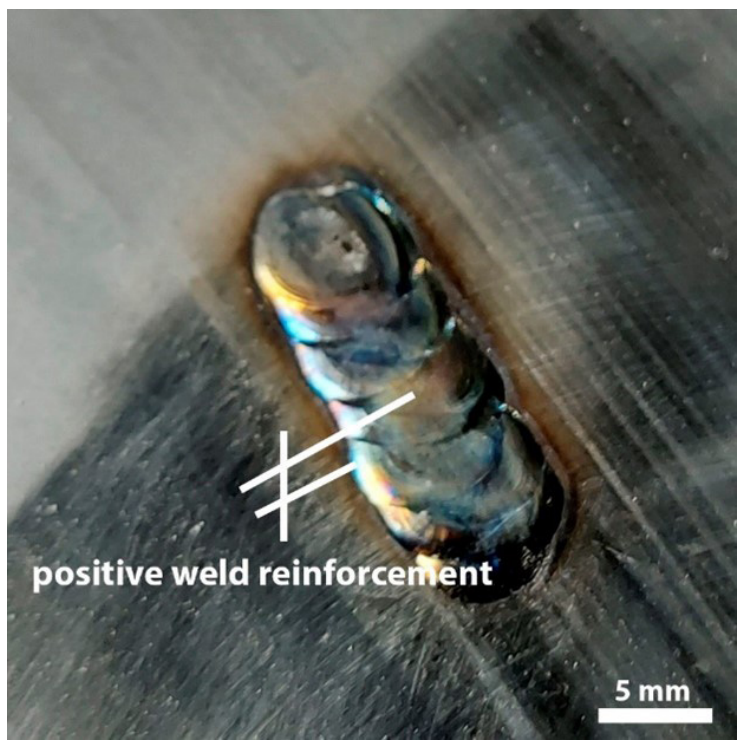

Figure 2. Weld bead made to repair the corrosion spot and its positive reinforcement in order to allow the mechanical polishing. treatment was based on both ASME BPE and ASTM A-380 Standards, and a customized irrigation device was used to spray the aqueous solution all over the surface.

The passivation level was measured for the ascontaminated condition and the repaired surface condition. The as-contaminated condition means the electrochemical measurements were performed on the surface tank as soon as the tank was available to the surface inspection process, and only a water flushing was applied before on-site electrochemical inspection. The inspected areas were near the localized corrosion spots (around $2 \mathrm{~mm}$ far) and on the base metal. The repaired surface condition is related to the surface finish obtained after all maintenance process, including chemical passivation treatment. For this case, the inspected areas were over the surface repaired by welding and polishing as well as on the base metal. Each condition was inspected in thirty surface spots by OCP and CPP resulting in a rate of 1/10 in terms of e-test numbers per square meter, and therefore this method provide a statistical confiability to the measurements.

For this purpose a customized portable electrochemical minicell ${ }^{16}$ with a capillary diameter of $1.5 \mathrm{~mm}$ was used, with a platinum counter electrode and an $\mathrm{Ag}|\mathrm{AgCl}| \mathrm{KCl}$ (3 $\mathrm{mol} \mathrm{L}^{-1}$ ) reference electrode, as shown in Figure 3. A Palmsens 4 potentiostat was operated using commercial PStrace 5.2 software, and a script was set up to perform the open circuit potential and cyclic polarization measurements in a sequence. The open circuit potential (OCP) was started immediately after the electrolyte contacting the surface and run for $30 \mathrm{~min}$, and all measurements were carried out at

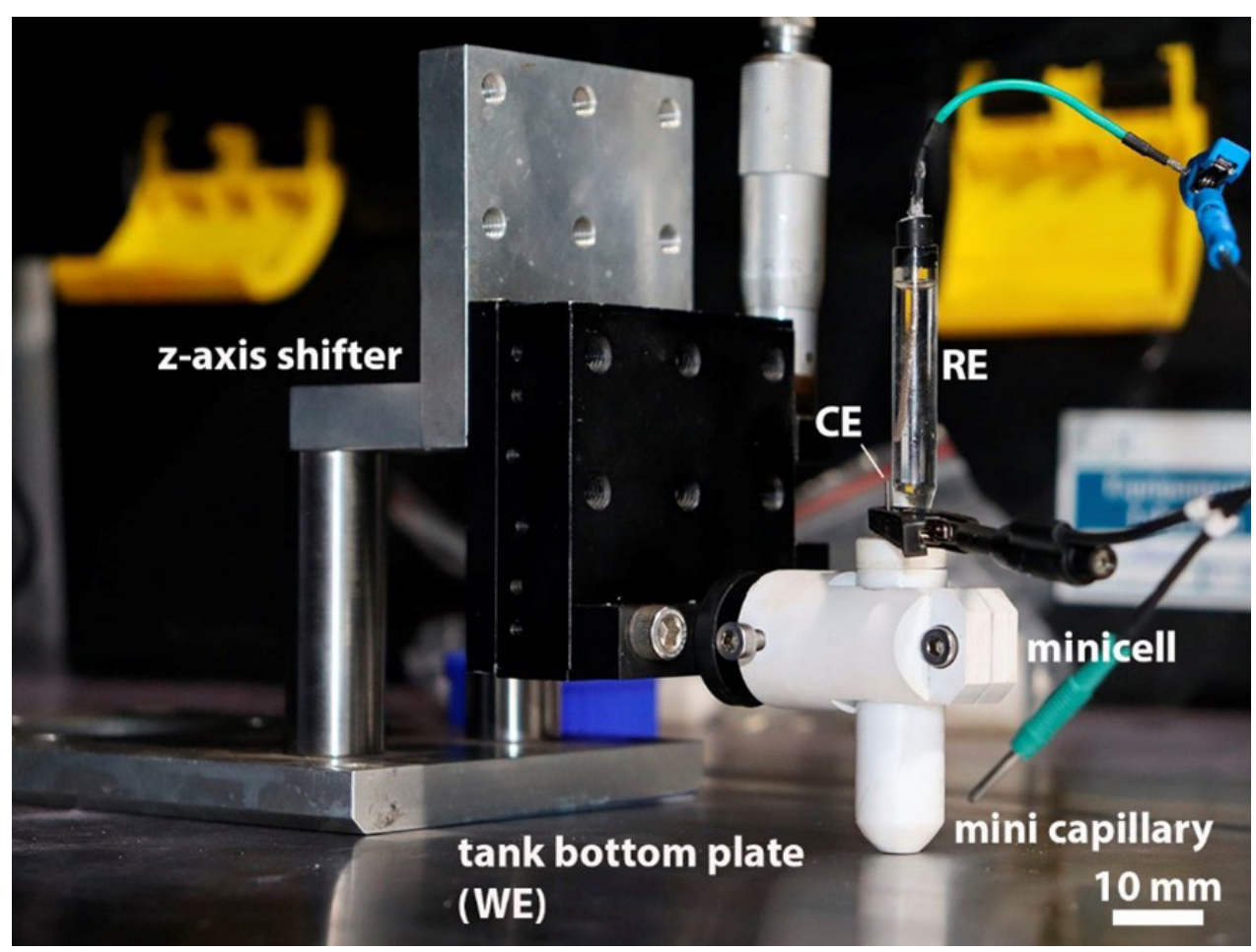

Figure 3. Portable electrochemical minicell using a capillary of $1.5 \mathrm{~mm}$. The working electrode (WE) is the bottom plate that was connected to the potentiostat; reference electrode (RE) is an $\mathrm{Ag}|\mathrm{AgCl}| \mathrm{KCl}(3 \mathrm{~mol} \mathrm{~L}-1)$ electrode with $5.0 \mathrm{~mm}$ diameter; counter electrode $(\mathrm{CE})$ is a titanium rod with a platinum wire involved in a spiral. 
inner tank temperature of $+5{ }^{\circ} \mathrm{C}$. Cyclic polarization tests (CPP) were performed in $3.5 \% \mathrm{NaCl}$ solution to evaluate the pitting corrosion resistance. After measurement of the OCP (30 min), an anodic polarization scan was performed at a sweep rate of $2.0 \mathrm{mV} \mathrm{s}^{-1}$. The anodic scan was reversed at a current density of $1 \mathrm{~mA} \mathrm{~cm}^{-2}$, with the sample then being scanned in the cathodic direction to a potential of $-200 \mathrm{mV}$ vs. OCP.

\section{Results and Discussion}

The passivation level of the AISI 316L stainless steel surface of the aseptic tank was evaluated and the passivity and corrosion resistance parameters were quantified through on-site cyclic polarization measurements. Representative OCP and CPP curves can be seen in Figure 4. All polarization curves showed a passive behavior and the electrochemical parameters used to quantify the passivation level were corrosion potential $\left(\mathrm{E}_{\text {corr }}\right)$, pitting potential $\left(\mathrm{E}_{\text {pit }}\right)$, protection potential $\left(\mathrm{E}_{\text {prot }}\right)$, and the passivation level was calculated as $\mathrm{E}_{\text {prot }}-\mathrm{E}_{\text {corr }}$, which represents the passive range ${ }^{27}$.

Initially, a large number of tests were performed on the as-contaminated surface. The base metal positions obtained a slightly better electrochemical parameters than those near to the corrosion spots, as can be seen in Table 1. It worth to highlight that the as-contaminated surface obtained a corrosion potential within the -166 to $-80 \mathrm{mV} / \mathrm{Ag}|\mathrm{AgCl}| \mathrm{KCl}(3 \mathrm{~mol} / \mathrm{L})$, and the pitting potential $\left(\mathrm{E}_{\mathrm{pit}}\right)$ between +329 to $+382 \mathrm{mV} /$ $\mathrm{Ag}|\mathrm{AgCl}| \mathrm{KCl}(3 \mathrm{~mol} / \mathrm{L})$. Furthermore, all measurements carried out showed a positive hysteresis after reversing the potential scan and the majority of them had a perform without protection potential (Figure $4 b$ ), resulting in a negative passivation level, since this parameter is defined by $\mathrm{E}_{\text {prot }}-\mathrm{E}_{\text {corr }}^{28}$.

The repaired surface showed the higher level of passivation and suitable to the AISI $316 \mathrm{~L}$ for aseptic applications, given that the open circuit potential registered was upper to $+180 \mathrm{mV} / \mathrm{Ag}|\mathrm{AgCl}| \mathrm{KCl}(3 \mathrm{~mol} / \mathrm{L})$, and the pitting potential was not observed and in additional a negative hysteresis was registered after reversing the potential scan, which means that stable pits were not nucleated in the tested conditions ${ }^{2}$. The passivated surface reached an average potential of $+500 \mathrm{mV} / \mathrm{Ag}|\mathrm{AgCl}| \mathrm{KCl}(3 \mathrm{~mol} / \mathrm{L})$ in the passive region. Another relevant comparation between tested surfaces is regarding passivation current density $\left(\mathrm{i}_{\text {pass }}\right)$. Considering the potential of $+300 \mathrm{mV} / \mathrm{Ag}|\mathrm{AgCl}| \mathrm{KCl}(3 \mathrm{~mol} / \mathrm{L})$, the $i_{\text {pass }}$ value of the repaired surface was $92 \%$ lower. Table 1 shows the electrochemical parameters obtained from on-site measurements for both surface conditions.

The AISI 316L stainless steel has been widely investigated in scientific research and it is possible comparing, in a relative way, the literature with the present experimental data. Although, it is important to point out that the comparation to the literature is restricted because of the difference between the experimental setup: surface finish and size of the exposed surface area in electrochemical measurements. This experimental investigation considered the industrial surface finish that is related to the average roughness of 0.76 micron (equivalent to 240 grinding paper) and reduced exposed surface area through using an electrochemical minicell. The literature has normally applied a higher polishing procedure and a larger exposed surface area, and as a result these differences can changes the electrochemical parameters ${ }^{8,29-31}$. In spite of the difference between the tests procedure, a similar result to the electrochemical parameters of the AISI 316L base metal was observed when compared the literature data ${ }^{32,33}$ with the previous studies of this research team in industrial measurements ${ }^{19}$. Both of them determine that the non-passivated AISI $316 \mathrm{~L}$ normally performs the pitting potential in the range from +400 to $+500 \mathrm{mV} / \mathrm{Ag}|\mathrm{AgCl}| \mathrm{KCl}(3 \mathrm{~mol} / \mathrm{L})$ and an average value to the corrosion potential can be defined as around $-180 \mathrm{mV} / \mathrm{Ag}|\mathrm{AgCl}| \mathrm{KCl}(3 \mathrm{~mol} / \mathrm{L})$. Based on that, the

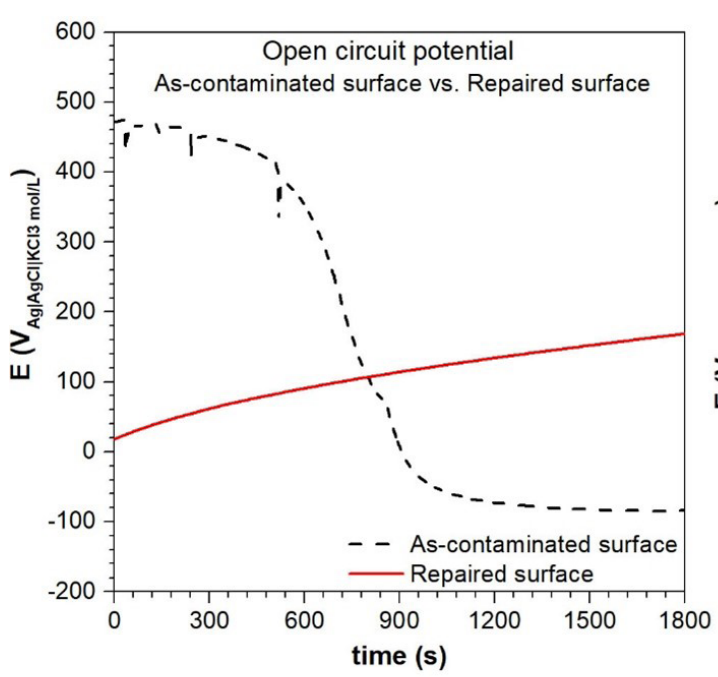

(a)

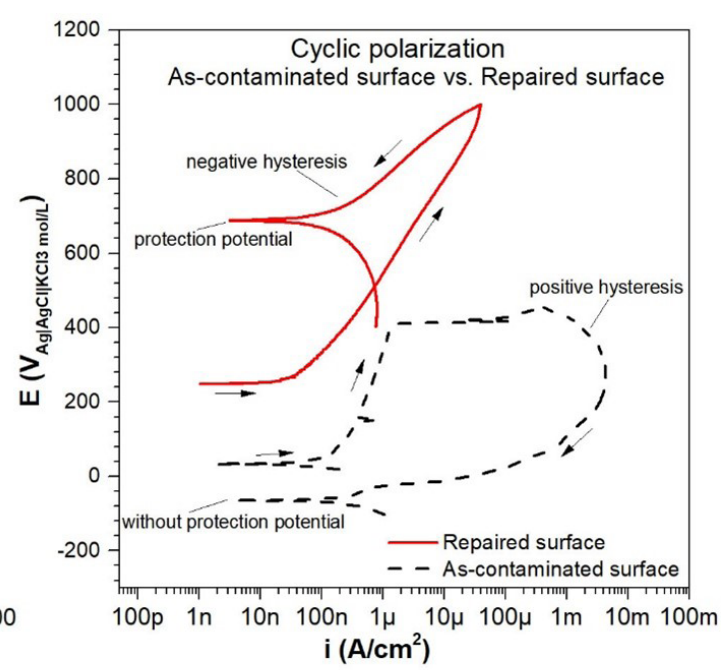

(b)

Figure 4. On-site electrochemical measurements to the AISI 316L aseptic tank comparing the surface conditions inspected: as-contaminated and repaired surfaces. It is showed in (a) open circuit potential curves and (b) cyclic polarization curves obtained at $2.0 \mathrm{mV} / \mathrm{s}$. Electrolyte: $3.5 \% \mathrm{NaCl}$ and $25{ }^{\circ} \mathrm{C}$. 
Table 1. Corrosion resistance parameters obtained from on-site OCP and CPP curves ${ }^{1}$.

\begin{tabular}{llccccc}
\hline \multirow{2}{*}{ Surface type } & \multicolumn{1}{c}{ Region } & $\begin{array}{c}\mathbf{i}_{\text {pass }(a+0.3 \mathrm{~V}} \\
\left(\mu \mathrm{A} / \mathrm{cm}^{2}\right)\end{array}$ & $\begin{array}{c}\mathbf{E}_{\text {corr }} \\
(\mathrm{mV})\end{array}$ & $\begin{array}{c}\mathbf{E}_{\text {prot }} \\
(\mathrm{mV})\end{array}$ & $\begin{array}{c}\mathbf{E}_{\text {pit }} \\
(\mathrm{mV})\end{array}$ & $\begin{array}{c}\text { Passivation } \\
\text { level }(\mathrm{mV})\end{array}$ \\
\hline \multirow{2}{*}{ As-contaminated surface } & Base metal & $0.86 \pm 0.08$ & $-80 \pm 19$ & $+59 \pm 22$ & $+382 \pm 19$ & $+139 \pm 18$ \\
\cline { 2 - 8 } & Near the corrosion spot & $1.3 \pm 0.1$ & $-166 \pm 29$ & $-195 \pm 32$ & $+329 \pm 31$ & $-29 \pm 26$ \\
\hline \multirow{2}{*}{ Repaired surface } & Base metal & $0.06 \pm 0.02$ & $+225 \pm 8$ & $+772 \pm 16$ & $+1000^{2}$ & $+547 \pm 10$ \\
\cline { 2 - 8 } & Repaired surface & $0.06 \pm 0.02$ & $+205 \pm 12$ & $+681 \pm 13$ & $+1000^{2}$ & $+476 \pm 13$ \\
\hline
\end{tabular}

${ }^{1}$ Each value in the table represents an average of 30 measured spots on the inspected surface. ${ }^{2} \mathrm{E}_{\mathrm{pit}}=1000 \mathrm{mV}$ means that the potential was scanned until $+1 \mathrm{~V}$ and the $\mathrm{E}_{\mathrm{pit}}$ was not registered. This behavior was noted for all repaired surface measurements.

as-contaminated surface obtained a pitting potential lower than the minimum average range highlighting that the lower values were registered near the corrosion spots. The main hypothesis is regarding the biofilm formation and its negative effect to the passive film, which cause a decrease in the electrochemical parameters obtained by CPP measurements ${ }^{21}$. On the other hand, it worth to point out that the corrosion potential should be run with a duration of at least $30 \mathrm{~min}$, because the immediately OCP value has been not reliable enough to support a decision about the passivation level of the stainless steel surface, as can be seen in Figure 4a. All in all, the CPP measurements were capable of measure that the passivation properties were reduced by industrial features.

The repaired surface showed a higher electrochemical parameters when compared to the as-contaminated surface and untreated surface in literature ${ }^{33}$, which means that the chemical passivation generated an improvement on the corrosion resistance as well as the portable electrochemical minicell was able to detect the difference between the surfaces. A similar improve on the AISI 316L surface was described by Nika Zakerin and Khashayar Morshed-Behbahani ${ }^{32}$ applying a passivation treatment in to AISI 316L stainless steel. The authors described that after chemical passivation treatment the OCP values changed from -200 to $+100 \mathrm{mV} /$ $\mathrm{Ag}|\mathrm{AgCl}| \mathrm{KCl}(3 \mathrm{~mol} / \mathrm{L})$ and the $\mathrm{E}_{\text {pit }}$ was not observed after treatment, similar to observed at this study in on-site inspections. Based on the corrosion potential and protection potential, the passivation level of the repaired surface shows a larger value and, in additional to that, the passivation current density was significantly reduced. These parameters are strong evidence that the chemical passivation treatment worked as a mechanism of increasing the corrosion resistance and it is indicating that the susceptibility to corrosion was drastically reduced. Moreover, the standard deviation of the electrochemical parameters was lower to the repaired surface, indicating that the passive film obtained by chemical passivation treatment was uniform and regular for all treated surfaces.

\section{Conclusion}

The on-site electrochemical inspection procedure was efficacy to assess and differentiate a degraded surface from a repaired surface, in terms of corrosion resistance. It was concluded that this procedure was able to quantify the passivation level as suggested by ASME BPE standard and it can be useful to validate the on-site maintenance services focused in repairing aseptic surfaces. On one hand, the CPP measurements were absolutely efficient and sensible to quantify the passivation properties and as a result the electrochemical parameters allowed to assess the passivation level of the surfaces. On the other hand, the OCP measurements needs to be carefully applied in order to assess the passivation level since the corrosion potential required at least $30 \mathrm{~min}$ to stablish and show a reliable value. It is important to highlight this condition because there are some passivation testers based on the OCP measurements that gives the results instantly, therefore, it can dispose to a wrong interpretation if used to assess the stainless steel surfaces. Even though the CPP test was efficient for this purpose, it is important to take account that this inspection procedure demands a surface polishing after the measurements because it should be considered destructive. An alternative for that is applying the electrochemical impedance spectroscopy (EIS) in onsite inspections, given that this technique does not cause any corrosion attack on the surface. This development for on-site inspections is in progress and so it will be a powerful alternative to assess the passivation level, biofilm and rouge formation in stainless steels equipments and facilities.

\section{Acknowledgements}

The authors would like to thank the São Paulo Research Foundation (FAPESP) for providing financial support for this research (Proc. no. 2019/23063-4).

\section{References}

1. Karayan AI, Castaneda H. Weld decay failure of a UNS S31603 stainless steel storage tank. Eng Fail Anal. 2014;44:351-62.

2. Sedriks AJ. Corrosion of stainless steels [Internet]. 1996 [cited 2021 Jan 27]. Available from: http://www.csa.com/partners/ viewrecord.php?requester=gs\&amp ;collection=TRD\&amp; recid=199907350041EMD

3. Hosseini AV, Karlsson L, Engelberg D, Wessman S. Timetemperature-precipitation and property diagrams for super duplex stainless steel weld metals. Weld World. 2018;62(3):517-33. http://dx.doi.org/10.1007/s40194-018-0548-z.

4. Reccagni P, Guilherme LH, Lu Q, Gittos MF, Engelberg DL. Reduction of austenite-ferrite galvanic activity in the heat-affected zone of a Gleeble-simulated grade 2205 duplex stainless steel weld. Corros Sci. 2019;161:108198. http://dx.doi.org/10.1016/j. corsci.2019.108198.

5. Guilherme LH, Reccagni P, Benedetti AV, Fugivara CS, Engelberg DL. Corrosion assessment of ASME qualified welding procedures for grade 2101 lean duplex stainless steel. Corrosion. 2019;75(10):1216-29. http://dx.doi.org/10.5006/3257.

6. Örnek C, Engelberg DL. SKPFM measured Volta potential correlated with strain localisation in microstructure to understand corrosion susceptibility of cold-rolled grade 2205 duplex stainless steel. Corros Sci. 2015;99:164-71. http://dx.doi.org/10.1016/j. corsci.2015.06.035. 
7. Guilherme LH, Della Rovere CA, Kuri SE, Oliveira MF. Corrosion behaviour of a dissimilar joint TIG weld between austenitic AISI $316 \mathrm{~L}$ and ferritic AISI 444 stainless steels. Weld Int. 2016;30(4):268-76. http://dx.doi.org/10.1080/09507116.2 015.1096476 .

8. Abodi LC, Dolgikh O, Terryn H, Deconinck J. The influence of the capillary size and shape on the readings of the electrochemical microcapillary technique: a parametric study by means of the multi-ion modeling. Electrochim Acta. 2016;189:128-36. http:// dx.doi.org/10.1016/j.electacta.2015.11.068.

9. Andreatta F, Fedrizzi L. The use of the electrochemical micro-cell for the investigation of corrosion phenomena. Electrochim Acta. 2015;203:337-49. http://dx.doi.org/10.1016/j. electacta.2016.01.099.

10. Pereda MD, Gervasi CA, Llorente CL, Bilmes PD. Microelectrochemical corrosion study of super martensitic welds in chloride-containing media. Corros Sci. 2011;53(12):3934-41. http://dx.doi.org/10.1016/j.corsci.2011.07.040.

11. Andreatta F, Matesanz L, Akita AH, Paussa L, Fedrizzi L, Fugivara CS, et al. SAE 1045 steel/WC-Co/Ni-Cu-Ni/SAE 1045 steel joints prepared by dynamic diffusion bonding: microelectrochemical studies in $0.6 \mathrm{M} \mathrm{NaCl}$ solution. Electrochim Acta. 2009;55(2):551-9. http://dx.doi.org/10.1016/j. electacta.2009.09.025.

12. Suter T, Bohni H. Microelectrodes for corrosion studies in microsystems. Electrochim Acta. 2001;47(1-2):191-9. http:// dx.doi.org/10.1016/S0013-4686(01)00551-5.

13. Suter T, Böhni H. A new microelectrochemical method to study pit initiation on stainless steels. Electrochim Acta. 1997;42(2022):3275-80. http://dx.doi.org/10.1016/S0013-4686(70)01783-8.

14. Böhni H, Suter T, Schreyer A. Micro- and nanotechniques to study localized corrosion. Electrochim Acta. 1995;40(10):13618. http://dx.doi.org/10.1016/0013-4686(95)00072-M.

15. Andreatta F, Lohrengel MM, Terryn H, De Wit JHW. Electrochemical characterisation of aluminium AA7075-T6 and solution heat treated AA7075 using a micro-capillary cell. Electrochim Acta. 2003;48(20-22):3239-47. http://dx.doi. org/10.1016/S0013-4686(03)00379-7.

16. Guilherme LH, Benedetti AV, Fugivara CS. A portable electrochemical microcell for weld inspection of duplex stainless steel tanks. Corrosion. 2019;75(4):340-8. http://dx.doi. org/10.5006/3004.

17. Guilherme LH, Fugivara CS, Benedetti AV. Corrosion monitoring of grade 2101 lean duplex stainless steel ASME BPE sanitary tanks by on-site cyclic polarization. In: $32^{\text {nd }}$ Canadian Materials Science Conference; 2021. Proceedings. Toronto: CMSC.; 2021.

18. Guilherme LH, Benedetti AV, Fugivara CS, Engelberg DL. Onsite passivation assessment of type $316 \mathrm{~L}$ aseptic storage tanks with electrochemical techniques. In: $21^{\text {st }}$ International Corrosion Congres; 2021. Proceedings. Rio de Janeiro: ABRACO; 2021.

19. Guilherme LH, Benedetti AV, Fugivara CS, Engelberg DL. Onsite cyclic polarization measurements to validate passivation treated AISI 316L stainless steel in a bio-fermentation tank. In: Eurocorr; 2021. Proceedings. Frankfurt am Main: European Federation of Corrosion; 2021.
20. Di Franco F, Tranchida G, Pupillo D, Ghersi G, Cinà P, Virtanen $\mathrm{S}$, et al. Effect of $E$. coli biofilm formation and removal on passive films on AISI $316 \mathrm{~L}$ during fermentation processes. Corros Sci. 2021;185:109430.

21. Mollica A, Cristiani P. On-line biofilm monitoring by 'BIOX' electrochemical probe. Water Sci Technol. 2003;47(5):45-9.

22. ASME: American Society of Mechanical Engineers. Bioprocessing equipment. New York: ASME BPE; 2019.

23. ASTM: American Society for Testing and Materials. ASTM A380: standard recommended practice for cleaning and descaling stainless steel parts, equipment, and systems. West Conshohocken: ASTM; 1972.

24. ASTM: American Society for Testing and Materials. ASTM A-240: standard specification for chromium and chromiumnickel stainless steel plate, sheet, and strip for pressure vessels and $\mathrm{f}$ or general applications. West Conshohocken: ASTM; 2004.

25. ASME: American Society of Mechanical Engineers. ASME boiler and pressure vessel code, section V: nondestructive examination. New York: ASME; 2019.

26. ASME: American Society of Mechanical Engineers. ASME Boiler and pressure vessel code, section IX: welding and Brazing qualifications. New York: ASME; 2019.

27. Kelly RG, Scully JR, Shoesmith D, Buchheit RG. Electrochemical techniques in corrosion science and engineering. New York: Marcel Dekker; 2002.

28. Esmailzadeh S, Aliofkhazraei M, Sarlak H. Interpretation of cyclic potentiodynamic polarization test results for study of corrosion behavior of metals: a review. Prot Met Phys Chem Surf. 2018;54(5):976-89. http://dx.doi.org/10.1134/ S207020511805026X.

29. Arjmand F, Adriaens A. Investigation of $304 \mathrm{~L}$ stainless steel in a $\mathrm{NaCl}$ solution using a microcapillary electrochemical droplet cell: comparison with conventional electrochemical techniques. Electrochim Acta. 2012;59:222-7. http://dx.doi.org/10.1016/j. electacta.2011.10.065.

30. Vignal V, Krawiec H, Le Manchet S. Influence of surface preparation and microstructure on the passivity and corrosion behaviour of duplex stainless steels. J Solid State Electrochem. 2014;18(11):2947-54. http://dx.doi.org/10.1007/s10008-0132364-0.

31. Guilherme LH, Benedetti AV, Fugivara CS, Magnabosco R, Oliveira MF. Effect of MAG welding transfer mode on sigma phase precipitation and corrosion performance of $316 \mathrm{~L}$ stainless steel multi-pass welds. J Mater ResTechnol. 2020;9(5):1053749. http://dx.doi.org/10.1016/j.jmrt.2020.07.039.

32. Zakerin N, Morshed-Behbahani K. Electrochemical insight into the Role of $\mathrm{H}_{2} \mathrm{O}_{2}$ in galvanostatic passivation of AISI $316 \mathrm{~L}$ austenitic stainless steel in citric acid electrolyte. Metall Mater Trans, A Phys Metall Mater Sci. 2021;52(8):3247-56. http:// dx.doi.org/10.1007/s11661-021-06283-9.

33. Yi Y, Cho P, Al Zaabi A, Addad Y, Jang C. Potentiodynamic polarization behaviour of AISI type 316 stainless steel in $\mathrm{NaCl}$ solution. Corros Sci. 2013;74:92-7. http://dx.doi.org/10.1016/j. corsci.2013.04.028. 